Jurnal Kesehatan Islam

Publkasi oleh Fakults Kedokteran, Universitas Islam Malang

Pages: 63 - 79

Email : jkesislam@unisma.ac.id

Home Page : http://riset.unisma.ac.id/index.php/jki

\title{
PERBEDAAN PENGARUH KONSELING DAN PENYULUHAN PERMASALAHAN MENYUSUI TERHADAP PENGETAHUAN, MOTIVASI, DAN KEMAMPUAN MENYUSUI SELAMA SATU BULAN PERTAMA PASCA PERSALINAN
}

\author{
Dewi Martha Indria ${ }^{*}$, Ari Natalia Probandari ${ }^{* *}$, Didik Tamtomo ${ }^{* *}$, \\ *Staf Pengajar Program Studi Pendidikan Dokter, Fakultas Kedokteran Universitas Islam Malang \\ *Mahasiswa Program Studi Pascasarjana Magister Kedokteran Keluarga, Universitas Sebelas Maret \\ Surakarta **Staf Pengajar Program Studi Pascasarjana Magister Kedokteran Keluarga, Universitas \\ Sebelas Maret Surakarta E-mail : dewimarthaindria@unisma.ac.id, ari.probandari@fk.uns.ac.id, \\ didik.tamtomo@fk.uns.ac.id
}

\begin{abstract}
Abstrak
Latar Belakang: Permasalahan menyusui umumnya menjadi penyebab dihentikannya pemberian ASI (Air Susu Ibu), durasi pemberian ASI menjadi lebih singkat dan secara dini dilakukan upaya untuk menggantikan atau memberikan suplementasi menggunakan susu formula atau Makanan Pendamping ASI (MPASI). Berdasarkan studi terdahulu, pendidikan kesehatan yang dilakukan dengan pendekatan tertentu ternyata mampu meningkatkan pengetahuan, kemampuan menyusui dan kepercayaan diri ibu dalam memberikan ASI pada bayi. Penelitian ini bertujuan untuk mengetahui perbedaan pengaruh dari dilakukannya konseling dan penyuluhan mengenai permasalahan menyusui yang dilakukan saat trimester akhir kehamilan terhadap pengetahuan, motivasi, dan kemampuan menyusui selama satu bulan pertama pasca persalinan.

Metode: Penelitian dilakukan di wilayah kerja Puskesmas Mojolangu dan Puskesmas Kendalkerep mulai dari kurun waktu Desember 2013 - April 2014. Rancangan penelitian yang dipakai adalah penelitian eksperimental dengan membagi sampel ke dalam dua kelompok perlakuan, yaitu kelompok yang mendapatkan konseling melalui kunjungan rumah dan kelompok penyuluhan yang terdiri dari masing-masing jumlah responden 23 orang. Penelitian melakukan penilaian hasil kuesioner pretest dan posttest mengenai pengetahuan dan motivasi menyusui serta pengamatan/observasi langsung kemampuan menyusuinya dengan praktik menyusui. Analisis data dilakukan dengan uji t-test dan uji Mann-Whitney (univariat dan bivariat), serta analisis multivariat menggunakan ANCOVA (Analysis of Covariance).

Hasil: Hasil penelitian menunjukkan bahwa baik konseling maupun penyuluhan mengenai permasalahan menyusui yang diberikan pada trimester akhir kehamilan secara signifikan mampu meningkatkan pengetahuan menyusui selama satu bulan pertama pasca persalinan dengan nilai $\mathrm{p}=0,000(\mathrm{p} \leq 0,05)$. Namun, jika dibandingkan antara konseling dan penyuluhan maka diantara keduanya tidak ada perbedaan yang bermakna. Sedangkan terkait motivasi menyusui dan kemampuan menyusui tidak didapatkan perbedaan pengaruh pada kedua kelompok perlakuan secara signifikan. Walaupun dari hasil rerata nilai, tampak bahwa rerata nilai motivasi dan observasi kemampuan menyusui pada kelompok konseling lebih baik daripada kelompok penyuluhan.
\end{abstract}

Kata kunci : konseling, penyuluhan, permasalahan menyusui, pengetahuan, motivasi, kemampuan menyusui, pasca persalinan

\section{PENDAHULUAN}

Air Susu Ibu (ASI) yang diberikan sejak usia dini dan dilanjutkan dengan ASI eksklusif selama 6 bulan pertama dapat menurunkan angka kesakitan dan angka kematian bayi serta meningkatkan tumbuh kembang bayi secara optimal. ${ }^{1}$ Prevalensi praktik pemberian ASI eksklusif di dunia hanya 34,8\% sedangkan di
Negara-negara Asia 46\%. ${ }^{2,3}$ Praktik pemberian ASI eksklusif di Indonesia secara keseluruhan cenderung menurun. Berdasarkan Hasil Survei Demografi Kesehatan Indonesia (SDKI) pada tahun 1997, 2003, 2007 memperlihatkan terjadinya penurunan persentase pemberian ASI eksklusif yaitu 40,2 \%, 39,5\%, dan $32 \%$. Sedangkan data survei nasional tahun 2004- 
2008 menunjukkan bahwa cakupan pemberian ASI eksklusif pada seluruh bayi di bawah usia 6 bulan meningkat dari 58,9\% (2004) menjadi $62,2 \%$ (2007). Namun menurun kembali Beberapa studi menunjukkan bahwa permasalahan dalam menyusui umumnya menjadi penyebab dihentikannya pemberian ASI, durasi pemberian ASI menjadi lebih singkat dan upaya menggantikan atau memberikan suplementasi dengan memberikan susu formula atau MPASI (Makanan Pendamping ASI) yang terlalu dini. ${ }^{6,7,8,9}$ Permasalahan menyusui umumnya muncul di usia enam bulan pertama. Studi yang dilakukan di Jakarta, Jerman, Kanada, dan India memperlihatkan bahwa 87,3\%, 67,8\%, $56,4 \%$, dan $46,1 \%$ dari sampel responden yang merupakan ibu menyusui mengalami setidaknya satu permasalahan menyusui selama memberikan ASI. ${ }^{6,7,8,10}$

Pendidikan kesehatan dengan pendekatan tertentu yang dilakukan oleh tenaga kesehatan memiliki pengaruh yang efektif terhadap adanya peningkatan pengetahuan ibu, kemampuan praktik menyusui serta kepercayaan ibu saat memberikan ASI pada bayinya. ${ }^{11}$ (Saleh et al., 2009). Siregar (2007) menunjukkan bahwa pengetahuan ibu yang rendah tentang manfaat ASI dapat mempengaruhi kemampuan ibu

menyusui bayinya. Faktor lain yang berpengaruh terhadap pemberian ASI selain pengetahuan, yaitu keyakinan dan motivasi untuk menyusui bayi. ${ }^{12}$

Berdasarkan penelitian yang dilakukan oleh Man Ku dan Chow (2010), didapatkan menjadi $56,2 \%$ pada tahun 2008. Hasil Riset Kesehatan Dasar (Riskesdas) tahun 2010 menunjukkan persentase ASI eksklusif 6 bulan

hanya $\quad 15,3 \quad \% .4,5$ bahwa praktik pemberian ASI pada ibu menyusui sangat dipengaruhi oleh keyakinan dan motivasi ibu. Ibu yang memiliki motivasi dan keyakinan diri yang baik dipercaya akan lebih mampu memberikan ASI jika dibandingkan dengan ibu yang memiliki motivasi dan keyakinan diri yang rendah. ${ }^{13}$

Pemberian informasi sangat penting dalam managemen penanganan permasalahan menyusui dengan menggunakan pendekatan atau teknik yang sesuai sehingga dapat mencegah munculnya permasalahan menyusui tersebut sejak awal. Jika permasalahan menyusui tetap muncul maka tenaga kesehatan, konselor laktasi, ibu menyusui dan juga keluarganya mengetahui bagaimana cara mengatasi permasalahan tersebut tanpa mengganggu proses menyusui yang berlangsung dan praktik pemberian ASI tetap berjalan. $^{14}$

Tujuan penelitian ini adalah untuk menganalisis perbedaan pengaruh dari dilakukannya konseling dan penyuluhan mengenai permasalahan menyusui selama trimester akhir kehamilan terhadap pengetahuan, motivasi, dan kemampuan menyusui selama satu bulan pertama pasca persalinan.

\section{METODE PENELITIAN}

Penelitian dilakukan di wilayah kerja Puskesmas Kendal Kerep dan Puskesmas 
Mojolangu yang berlokasi masing-masing di wilayah Kecamatan Blimbing dan Kecamatan Lowokwaru, Kota Malang. Pelaksanaan penelitian dilakukan pada tahapan waktu berikut ini pengambilan data primer sejak bulan Desember 2013 - Januari 2014 dan penelitian : bulan Januari - April 2014.

Rancangan penelitian menggunakan pendekatan kuantitatif dengan rancangan penelitian true experimental pretest-posttest control group design. Penelitian ini membagi sampel kedalam dua kelompok yaitu kelompok yang mendapatkan konseling (perlakuan) dan kelompok penyuluhan (kontrol positif).

Pada desain penelitian, kedua kelompok perlakuan tersebut akan diberikan kuesioner pretest terlebih dahulu, yang bertujuan untuk menilai pengetahuan dan motivasi menyusui sebelum diberikan intervensi. Sesudah diberikan intervensi, akan dilanjutkan penilaian hasil melalui kuesioner posttest. Intervensi yang akan dilakukan pada penelitian ini adalah metode promosi kesehatan secara individual dengan konseling melalui kunjungan rumah yang akan diberikan pada kelompok pertama dan metode promosi kesehatan secara berkelompok dengan penyuluhan yang akan diberikan pada kelompok kedua.

Yang menjadi populasi dalam penelitian ini adalah ibu hamil yang ada di wilayah Kecamatan Lowokwaru dan Kecamatan Blimbing, Kota Malang. Cara pengambilan sampel dilakukan dengan two stage cluster sampling. Penentuan besar sampel menggunakan rumus uji hipotesis beda 2 mean kelompok independen. Dari hasil perhitungan didapatkan jumlah sampel 25 orang pada masing-masing kelompok perlakuan dan kelompok kontrol.

Kriteria inklusi dalam penelitian ini adalah ibu hamil yang bersedia untuk menjadi sampel dalam penelitian sampai batas waktu yang telah ditentukan yaitu mulai dari usia kehamilan trimester ketiga sampai satu bulan pasca persalinan dengan asumsi bahwa sampel akan melahirkan paling lama tiga bulan ke depan, sehat, melahirkan bayi tunggal dan sehat dengan berat badan bayi lahir lebih atau sama dengan 2500 gram tanpa ada cacat bawaan pada bayi.

Sedangkan kriteria eksklusi dalam penelitian ini adalah ibu yang tidak dapat membaca dan menulis serta ibu yang melahirkan disertai dengan komplikasi sesudah melahirkan. Dalam kurun waktu tersebut responden penelitian diharapkan mampu memahami dan mau melaksanakan pesan-pesan yang disampaikan saat konseling dan penyuluhan sehingga memiliki kemampuan untuk menghadapi permasalahan dalam pemberian ASI dan pada akhirnya mau mempraktikkan pemberian ASI.

Pemberian perlakuan dan pengambilan data dilakukan oleh peneliti dan 3 orang Konselor Laktasi dari Asosiasi Ibu Menyusui Indonesia ranting Malang yang sudah mengikuti Pelatihan Konseling Menyusui Modul 40 jam (Standar WHO/KEMKES/UNICEF) dan telah 
memperoleh sertifikat sebagai konselor laktasi. Pemberian perlakuan dan pengambilan data dilakukan beberapa tahap (mengikuti waktu kehamilan dan persalinan responden). Perlakuan (konseling dengan konseling dan penyuluhan berkelompok) diberikan pada masa trimester akhir lalu evaluasi akhir dilakukan pada saat bayi berusia 1 bulan.

Instrumen yang digunakan dalam penelitian ini adalah formulir persetujuan keikutsertaan dalam penelitian, kuesioner penilaian pengetahuan menyusui, kuesioner penilaian motivasi menyusu, formulir pemantauan praktik pemberian ASI (lembar observasi WHO).

Kuesioner untuk menilai pengetahuan tentang permasalahan dalam pemberian ASI dan durasi menyusui. Kuesioner berisi 10 pertanyaan, 4 diantaranya merupakan pertanyaan mengenai durasi menyusui dan 6 yang lainnya mengenai permasalahan dalam pemberian ASI. Kuesioner ini digunakan pada penelitian terdahulu yang telah diuji validitasnya oleh Manjilala (2012). ${ }^{9}$ Sistem penilaian kuesioner dengan rentang skor $1-10$.

Motivasi ibu dalam pemberian ASI dinilai dengan menggunakan kuesioner modifikasi dari "Breastfeeding Motivational Instructional Measuremant Scale (BMIMS)", 15 Kuesioner ini terdiri dari 17 pertanyaan tertutup
(15 pertanyaan positif dan 3 pertanyaan negatif). Pengukuran menggunakan skala Likert yaitu Sangat Setuju (SS), Setuju (S), Kurang Setuju (KS), dan Tidak Setuju (TS).

Kemampuan menyusui ibu dinilai dengan menggunakan instrumen observasi lembar bantuan pengamatan menyusui WHO (2011) dalam buku Pelatihan Konseling Menyusui. ${ }^{1}$ Observasi dilakukan pada saat penilaian akhir (posttest) sesudah diberikan intervensi. Lembar observasi ini digunakan oleh observer (peneliti dan asisten peneliti). Kegiatan menyusui yang diobservasi terdiri dari 15 tindakan. Skor jawaban menggunakan skala nominal yaitu ya (jika dilakukan oleh ibu) dan tidak (jika tidak dilakukan oleh ibu).

Analisis data dilakukan secara kuantitatif yang disesuaikan dengan tujuan yang akan dicapai pada penelitian ini, dengan uji statistik yang meliputi analisis univariat, bivariat, dan multivariat. Analisis univariat dilakukan dengan statistik deskriptif.

Pemilihan uji statistik untuk analisis bivariat yang digunakan dapat dilihat pada tabel 1 . Sedangkan Hubungan antara variabel bebas dengan variabel tergantung dan pengaruh variabel luar dikendalikan dengan analisis multivariate dengan menggunakan uji statistik Analysis of Covariance (ANCOVA).

Tabel $1 \quad$ Pemilihan Uji Statistik pada Analisis Bivariat

\begin{tabular}{|c|c|}
\hline Uji Statistik & Variabel \\
\hline$t$-dependent paired test & $\bullet$ Perbedaan pengetahuan menyusui sebelum intervensi (pretest) dan sesudah \\
\hline
\end{tabular}




\begin{tabular}{|c|c|}
\hline & $\begin{array}{l}\text { intervensi (posttest) pada kelompok konseling } \\
\text { - Perbedaan pengetahuan menyusui sebelum intervensi (pretest) dan sesudah } \\
\text { intervensi (posttest) pada kelompok penyuluhan }\end{array}$ \\
\hline Wilcoxon & $\begin{array}{l}\text { - Perbedaan motivasi menyusui sebelum intervensi (pretest) dan sesudah } \\
\text { intervensi (posttest) pada kelompok konseling } \\
\text { - Perbedaan motivasi menyusui sebelum intervensi (pretest) dan sesudah } \\
\text { intervensi (posttest) pada kelompok penyuluhan }\end{array}$ \\
\hline Mann-Whitney & $\begin{array}{l}\text { - Perbedaan motivasi menyusui sebelum intervensi (pretest) pada kelompok } \\
\text { konseling dan penyuluhan } \\
\text { - Perbedaan motivasi menyusui setelah intervensi (posttest) pada kelompok } \\
\text { konseling dan penyuluhan } \\
\text { - Perbedaan pengetahuan menyusui setelah intervensi (posttest) pada kelompok } \\
\text { konseling dan penyuluhan } \\
\text { - Perbedaan skor observasi kemampuan menyusui pada kelompok konseling dan } \\
\text { penyuluhan }\end{array}$ \\
\hline t-independent test & $\begin{array}{l}\text { - Perbedaan pengetahuan menyusui sebelum intervensi (pretest) pada kelompok } \\
\text { konseling dan penyuluhan } \\
\text { - Perbedaan selisih pengetahuan menyusui pada kelompok konseling dan } \\
\text { penyuluhan } \\
\text { - Perbedaan selisih motivasi menyusui pada kelompok konseling dan penyuluhan }\end{array}$ \\
\hline
\end{tabular}

\section{HASIL DAN PEMBAHASAN}

Karakteristik ibu hamil yang menjadi responden penelitian mayoritas dari karakter usia berada pada rentang usia 25 - 30 tahun (42,3\% pada kelompok konseling dan $44 \%$ pada kelompok penyuluhan), hampir sebagian besar responden adalah ibu rumah tangga (tidak bekerja). Ditinjau dari tingkat pendidikan ibu, pada kelompok konseling, penyebaran rentang pendidikan ibu hampir merata baik pada pendididan dasar, menengah maupun tinggi. Namun pada kelompok penyuluhan, tingkat pendidikan mayoritas berada pada rentang pendidikan menengah sebesar $56 \%$ dari keseluruhan total responden penelitian di kelompok tersebut. Untuk tingkat ekonomi keluarga, baik pada kelompok konseling maupun penyuluhan, hampir sebagian besar berada pada status perekonomian rendah dengan jumlah penghasilan rata-rata tiap bulan di bawah $\mathrm{Rp}$ 1.500.000,00 (61,5\% pada kelompok konseling dan $72 \%$ pada kelompok penyuluhan). Dari hasil analisis Chi-square didapatkan pada semua karakteristik responden memiliki nilai $\mathrm{p}>0,05$, sehingga dapat disimpulkan bahwa ada homogenitas di antara kedua kelompok perlakuan (Tabel 2).

Tabel 2 Karakteristik Responden Penelitian

\begin{tabular}{lcccc}
\hline Karakteristik & $\begin{array}{c}\text { Kelompok } \\
\text { Konseling }\end{array}$ & $\begin{array}{c}\text { Kelompok } \\
\text { Penyuluhan }\end{array}$ & $95 \%$ CI & P value \\
\hline Usia ibu & & & $0,668-0,686$ & $0,656^{*}$ \\
$<25$ & $5(19,2 \%)$ & $7(28 \%)$ & & \\
$25-30$ & $11(42,3 \%)$ & $11(44 \%)$ & &
\end{tabular}




\begin{tabular}{|c|c|c|c|c|}
\hline$>30$ & $10(38,5 \%)$ & $7(28 \%)$ & & \\
\hline Tingkat pendidikan ibu & & & $0,337-0,356$ & $0,299 *$ \\
\hline Pendidikan dasar & $10(38,5 \%)$ & $7(28 \%)$ & & \\
\hline Pendidikan menengah & $9(34,6 \%)$ & $14(56 \%)$ & & \\
\hline Pendidikan tinggi & $7(26,9 \%)$ & $4(16 \%)$ & & \\
\hline Pekerjaan ibu & & & & $0,679 *$ \\
\hline Bekerja & $5(19,2 \%)$ & $6(24 \%)$ & & \\
\hline Tidak bekerja & $21(80,8 \%)$ & $19(76 \%)$ & & \\
\hline Tingkat ekonomi keluarga & & & $0,618-0,637$ & $0,556^{*}$ \\
\hline$<1.500 .000$ & $16(61,5 \%)$ & $18(72 \%)$ & & \\
\hline $1.500 .000-3.000 .000$ & $7(26,9 \%)$ & $6(24 \%)$ & & \\
\hline$>3.000 .000$ & $3(11,5 \%)$ & $1(4 \%)$ & & \\
\hline Jenis persalinan & & & & $0,843 *$ \\
\hline Persalinan spontan normal & $17(65,4 \%)$ & $17(68 \%)$ & & \\
\hline Persalinan dengan pembedahan & $9(34,6 \%)$ & $8(32 \%)$ & & \\
\hline Paritas & & & $0,408-0,428$ & $0,393 *$ \\
\hline Primipara & $7(26,9 \%)$ & $11(44 \%)$ & & \\
\hline Sekundipara & $15(57,7 \%)$ & $10(40 \%)$ & & \\
\hline Multipara & $4(15,4 \%)$ & $4(16 \%)$ & & \\
\hline Usia berakhirnya kehamilan & & & & $0,157 *$ \\
\hline Preterm & & - & & \\
\hline Aterm & $24(92,3 \%)$ & $2(7,7 \%)$ & & \\
\hline Postterm & $25(100 \%)$ & $0(0 \%)$ & & \\
\hline Berat bayi lahir & & & $0,134-0,147$ & $0,109 *$ \\
\hline $2500-3000$ & $10(43,5 \%)$ & $9(39,1 \%)$ & & \\
\hline $3000-3500$ & $12(52,5 \%)$ & $8(34,8 \%)$ & & \\
\hline $3500-4000$ & $1(4,3 \%)$ & $6(26,1 \%)$ & & \\
\hline
\end{tabular}

Keterangan : (*) Chi-square test

\section{Pengetahuan Menyusui}

Pemberian informasi sebagai salah satu strategi perubahan perilaku mampu meningkatkan pengetahuan. Peningkatan pengetahuan akan menimbulkan kesadaran sehingga seseorang akan berperilaku sesuai dengan pengetahuan atau informasi yang didapatkannya. Beberapa upaya pemberian informasi dapat dilakukan dalam bentuk pendampingan (konseling) dan penyuluhan. ${ }^{16}$

Pada kelompok konseling, pemberian perlakuan dilakukan pendampingan langsung dengan tujuan terjadi kontak yang lebih intensif antara peneliti/asisten peneliti dengan responden. Setiap permasalahan yang mungkin atau pernah dihadapi oleh responden berdasarkan pengalaman menyusui sebelumnya bisa dikelola dan dibantu penyelesaiannya sehingga pada saat menghadapi masa menyusui pasca persalinan, responden merasa mampu dan lebih siap mengatasinya. Pada akhirnya responden diharapkan berdasarkan kesadarannya akan menerima informasi yang disampaikan saat perlakuan dan dengan penuh pengertian mampu meningkatkan kemampuan menyusuinya sehingga praktik pemberian ASI eksklusif dapat meningkat.

Walaupun memiliki tujuan dan manfaat yang sama dengan kegiatan pendampingan konseling, akan tetapi penyuluhan dalam 
kelompok kecil maupun besar memiliki keterbatasan seperti waktu untuk diskusi mendalam yang terbatas serta pembahasan topik permasalahan akan menjadi lebih sulit dilakukan karena responden yang hadir bersama-sama di dalam satu penyuluhan tentunya memiliki latar belakang pemahaman dan budaya yang berbedabeda. ${ }^{17}$ Sehingga secara tidak langsung dapat mempengaruhi tingkat penyerapan dan pemahaman yang berbeda-beda pada tiap individu yang ikut terlibat sebagai peserta penyuluhan (responden penelitian).

Berdasarkan hasil penelitian ini, baik pada kelompok konseling maupun kelompok penyuluhan diketahui terdapat peningkatan nilai rata-rata hasil kuesioner pengetahuan menyusui baik sebelum dilakukan perlakuan maupun sesudah perlakuan. Secara statistik juga didapatkan adanya perbedaan yang bermakna antara rata-rata nilai pengetahuan sebelum dengan sesudah dilakukannya perlakuan (Tabel $3)$.

Hal ini sejalan dengan penelitian lain yang dilakukan oleh Sari (2009) yang membuktikan adanya pengaruh penyuluhan manajemen laktasi terhadap pengetahuan bidan dengan hasil yang signifikan membuktikan adanya peningkatan pengetahuan nilai posttest setelah dilakukan perlakuan dibandingkan dengan sebelum perlakuan (nilai pretest). ${ }^{18} \mathrm{Hal}$ ini sesuai dengan yang diutarakan oleh Green (1980) bahwa pendekatan edukasional dapat merubah perilaku dan pengetahuan seseorang. Proses perubahan perilaku oleh penyampaian pendidikan kesehatan ini dipengaruhi oleh banyak faktor. 16

Salah satu faktor yang mempengaruhi adalah metode yang diberikan pada saat penyuluhan maupun konseling. Studi oleh Muslikha dan Purwanti (2011) yang melakukan promosi kesehatan menggunakan media leaflet menyimpulkan bahwa adanya peningkatan tingkat pengetahuan ibu mengenai ASI eksklusif setelah dilakukan penyuluhan dengan media promosi kesehatan. ${ }^{19}$

Jika dilihat dari hasil perbedaan selisih nilai pengetahuan menyusui pada kedua kelompok perlakuan tidak didapatkan perbedaan yang signifikan diantara kedua kelompok tersebut walaupun dari nilai rata-rata didapatkan selisih nilai pada kelompok penyuluhan lebih tinggi daripada selisih nilai pada kelompok konseling. Hal ini kemungkinan dipengaruhi oleh karakteristik responden penelitian yaitu dari tingkat pendidikan ibu.

Tabel 3 Perbedaan Nilai Rata-rata Pretest dan Posttest Pengetahuan Menyusui antara Kelompok Konseling dan Kelompok Penyuluhan

\begin{tabular}{|c|c|c|c|c|c|c|}
\hline Variabel & $\mathrm{n}$ & Mean & SD & $95 \% \mathrm{CI}$ & Nilai t & $\begin{array}{l}\text { P value } \\
\text { (paired } \\
\text { t-test) }\end{array}$ \\
\hline \multicolumn{7}{|c|}{ Kelompok Konseling } \\
\hline Pretest & 26 & 6,00 & 2,433 & & & \\
\hline Posttest & 26 & 7,88 & 1,925 & & & \\
\hline
\end{tabular}




\begin{tabular}{|c|c|c|c|c|c|c|}
\hline Pretest - Posttest & & $-1,885$ & 1,751 & $(-2,592)-(-1,177)$ & $-5,488$ & $0,000^{*}$ \\
\hline \multicolumn{7}{|c|}{ Kelompok Penyuluhan } \\
\hline Pretest & 25 & 5,20 & 2,533 & & & \\
\hline Posttest & 25 & 7,56 & 1,635 & & & \\
\hline Pretest - Posttest & 25 & $-2,360$ & 2,481 & $(-3,384)-(-1,336)$ & $-4,756$ & $0,000^{*}$ \\
\hline
\end{tabular}

Ket : $\left(^{*}\right) \mathrm{p}$ value $\leq 0,05=$ perbedaan yang signifikan

Studi deskripsi karakteristik responden penelitian menunjukkan homogenitas tingkat pendidikan ibu antara kedua kelompok. Namun dari data hasil penelitian didapatkan bahwa pada kelompok penyuluhan, mayoritas responden berasal dari tingkat pendidikan menengah (SMU). Hal tersebut berbeda dengan karakter tingkat pendidikan ibu di kelompok konseling yang mayoritas berada pada tingkat pendidikan dasar (SD, SMP).

Jika dilihat dari hasil perbedaan selisih nilai pengetahuan menyusui pada kedua kelompok perlakuan tidak didapatkan perbedaan yang signifikan diantara kedua kelompok tersebut walaupun dari nilai rata-rata didapatkan selisih nilai pada kelompok penyuluhan lebih tinggi daripada selisih nilai pada kelompok konseling. Hal ini kemungkinan dipengaruhi oleh karakteristik responden penelitian yaitu dari tingkat pendidikan ibu. Studi deskripsi karakteristik responden penelitian menunjukkan homogenitas tingkat pendidikan ibu antara kedua kelompok. Namun dari data hasil penelitian didapatkan bahwa pada kelompok penyuluhan, mayoritas responden berasal dari tingkat pendidikan menengah (SMU). Hal tersebut berbeda dengan karakter tingkat pendidikan ibu di kelompok konseling yang mayoritas berada pada tingkat pendidikan dasar (SD, SMP).

Karakteristik responden lainnya yang mungkin dapat berpengaruh pada perbedaan nilai rata-rata pengetahuan diantara kedua kelompok perlakuan adalah jumlah paritas. Jika dilihat dari karakteristik responden pada penelitian ini ditemukan pada kelompok konseling mayoritas responden adalah ibu dengan riwayat paritas sekundipara (saat dilakukan penelitian sedang hamil anak kedua) dengan persentase sebesar $57,7 \%$.

Sedangkan pada kelompok penyuluhan mayoritas responden adalah ibu dengan riwayat paritas primipara (saat dilakukan penelitian sedang hamil anak pertama). Jumlah paritas berkaitan dengan pengalaman memiliki anak dan menyusui sebelumnya. Studi yang dilakukan oleh Aswa (2010) tidak ditemukan adanya hubungan antara paritas dengan pemberian ASI eksklusif. ${ }^{20}$ Penelitian lain yang dilakukan oleh Van Gobel, et al. (2013) juga menunjukkan bahwa ibu dengan paritas lebih dari satu memiliki peluang memberikan ASI eksklusif pada bayinya lebih tinggi dibandingkan dengan ibu yang berparitas satu (primipara). ${ }^{21}$ Hal yang berbeda ditemukan di dalam studi yang dilakukan untuk menganalisis faktor-faktor resiko kegagalan dalam pemberian 
ASI oleh Hikmawati (2008). Studi tersebut menunjukkan bahwa terdapat hubungan yang bermakna antara paritas dengan pemberian ASI. $^{22}$ Menurut Pechlivani, et al. (2005), ibu multipara menunjukkan angka yang lebih tinggi dalam memberikan ASI eksklusif dibandingkan dengan ibu primipara. ${ }^{23}$

Informasi dan pengetahuan mengenai ASI dan menyusui ternyata memiliki pengaruh yang cukup kuat untuk membantu ibu menghadapi permasalahan dalam menyusui dan secara tidak langsung akan mempengaruhi durasi menyusui. Bagi ibu, akses untuk mendapatkan pengetahuan tentang ASI menjadi sangat penting terutama jika pengetahuan tersebut disampaikan oleh seseorang yang memiliki kompetensi yang baik ditinjau dari kemampuan dan keterampilannya dalam menguasai informasi yang akan disampaikan dan mendukung penuh pemberian $\mathrm{ASI}^{24}$ Baik konseling maupun penyuluhan merupakan metode pendidikan kesehatan yang dapat dilakukan untuk meningkatkan pengetahuan ibu mengenai menyusui. Bagaimanapun juga, yang harus diperhatikan tidak hanya siapa yang menyampaikan informasi tersebut, namun juga seberapa mampu penyampai informasi memberikan informasi yang tepat dan berimbang mengenai ASI. ${ }^{14}$

\section{Motivasi Menyusui}

Berdasarkan

penelitian Racine, et al.

(2011), pengalaman menyusui mampu mempengaruhi motivasi ibu memberikan ASI.

Motivasi ibu dipengaruhi oleh faktor intrinsik yaitu pemberian informasi dan pengetahuan menyusui serta faktor ekstrinsik yang berasal dari dukungan keluarga, suami, tenaga kesehatan dan pengaruh sosial budaya masyarakat sekitar. ${ }^{25}$ Kurangnya pengetahuan dan dukungan dari tenaga kesehatan juga memiliki pengaruh terhadap motivasi ibu memberikan ASI pada bayinya. ${ }^{15}$

Dari tabel 4 terlihat bahwa pada kelompok konseling diketahui, rerata nilai pretest motivasi responden sebelum perlakuan adalah 63,92 (SD 4,454). Setelah dilakukan perlakuan (konseling dengan kunjungan rumah), rerata nilai posttest motivasi responden mengalami penurunan menjadi 62,35 (SD 5,140). Dari hasil analisis uji normalitas dengan uji Shapiro-Wilk yang dilakukan pada variabel nilai pretest motivasi pada kelompok konseling didapatkan hasil nilai $\mathrm{p} 0,000$ dan nilai posttest hasil nilai $\mathrm{p} 0,043(<0,05)$, sehingga dapat disimpulkan bahwa distribusi nilai pretest maupun posttest variabel motivasi responden kelompok konseling sebelum perlakuan dan sesudah perlakuan tidak berdistribusi normal.

Dari tabel 4 dapat dilihat bahwa pada kelompok penyuluhan diketahui, rerata nilai pretest motivasi responden sebelum perlakuan adalah 61,92 (SD 5,729). Setelah dilakukan perlakuan (penyuluhan dalam kelompok), rerata nilai posttest motivasi responden mengalami penurunan menjadi 61,78 (SD 5,469). 
Tabel 4 Tabel Deskripsi Distribusi Data Nilai Motivasi Pretest, Posttest serta Selisih Posttest dan Pretest mengenai Pemberian ASI Pada Kelompok Perlakuan

\begin{tabular}{|c|c|c|c|c|c|c|c|}
\hline Variabel & $\mathrm{n}$ & Min-Max & Mean & Med & SD & 95\% CI Mean & $\begin{array}{c}\text { P Value } \\
\text { (Shapiro- } \\
\text { Wilk) }\end{array}$ \\
\hline \multicolumn{8}{|c|}{ Kelompok Konseling } \\
\hline Pretest & 26 & $46-68$ & 63,92 & 65,00 & 4,454 & $62,12-65,72$ & 0,000 \\
\hline Posttest & 23 & $49-68$ & 62,35 & 63,00 & 5,140 & $60,13-64,57$ & 0,043 \\
\hline Selisih & 23 & $(-12)-4$ & $-1,57$ & 0,00 & 4,251 & $-3,40-0,27$ & $0,058 *$ \\
\hline \multicolumn{8}{|c|}{ Kelompok Penyuluhan } \\
\hline Pretest & 25 & $48-68$ & 61,92 & 63,00 & 5,729 & $59,55-64,29$ & 0,004 \\
\hline Posttest & 23 & $52-68$ & 61,78 & 63,00 & 5,469 & $59,42-64,15$ & 0,016 \\
\hline Selisih & 23 & $(-10)-8$ & $-0,65$ & $-1,00$ & 4,355 & $-2,54-1,23$ & $0,509 *$ \\
\hline
\end{tabular}

Ket $:(*) p$ value $\geq 0,05=$ distribusi data normal

Dari hasil analisis uji normalitas dengan uji Shapiro-Wilk yang dilakukan pada variabel nilai pretest motivasi pada kelompok penyuluhan didapatkan hasil nilai p 0,004 dan nilai posttest hasil nilai p 0,016 (< 0,05$)$, sehingga dapat disimpulkan bahwa distribusi nilai pretest maupun posttest variabel motivasi responden kelompok konseling tidak berdistribusi normal.

Dari tabel 4 juga dapat dilihat selisih nilai posttest dan pretest motivasi pada kelompok konseling memiliki rerata nilai selisih -1,57 (SD 4,251) dan kelompok penyuluhan memiliki rerata nilai selisih -0,65 (SD 4,355). Dari hasil uji analisis normalitas dengan uji Shapiro-Wilk pada selisih nilai motivasi masingmasing kedua kelompok perlakuan didapatkan nilai p 0,058 (kelompok konseling) dan 0,509 (kelompok penyuluhan). Nilai nilai $\mathrm{p}$ kedua kelompok tersebut memenuhi syarat distribusi data normal dengan nilai $\mathrm{p}>0,05$.

Hasil penelitian ini, didapatkan hanya pada kelompok konseling yang memberikan perbedaan yang signifikan antara rata-rata nilai motivasi sebelum dengan sesudah dilakukannya intervensi. Sehingga dapat disimpulkan, konseling lebih berpengaruh dalam meningkatkan motivasi menyusui daripada penyuluhan. Hal ini dapat ditunjukkan pada penelitian ini dimana pada kelompok konseling nilai rata-rata skor motivasinya lebih tinggi daripada kelompok penyuluhan. Pada saat dilakukan konseling, pendidikan atau informasi yang diberikan menempatkan ibu sebagai subjek dan bukan objek sehingga hal ini akan membuat ibu menaruh minat yang besar untuk mengikuti konseling. Hal ini tentu saja mampu memotivasi ibu untuk mengetahui lebih lanjut mengenai informasi yang disampaikan saat konseling. Studi yang dilakukan oleh Ambarwati (2013), memperlihatkan bahwa konseling intensif tidak hanya meningkatkan pengetahuan namun juga sikap ibu dalam pemberian ASI yang bersumber dari motivasi untuk memberikan nutrisi yang terbaik bagi bayinya. $^{26}$

Hal ini sejalan dengan penelitian yang dilakukan oleh Suryaningsih (2012), yang melakukan penelitian terhadap 38 responden ibu menyusui dan mendapatkan hasil bahwa terdapat peningkatan motivasi Ibu dalam 
pemberian ASI sesudah dilakukan intervensi dengan demonstrasi dan pendampingan menyusui pasca persalinan. ${ }^{27}$ Studi oleh

Muslikha dan Purwanti (2012) juga menyimpulkan bahwa motivasi ibu menyusui untuk memberikan ASI eksklusif meningkat setelah diberikan leaflet tentang ASI eksklusif. ${ }^{19}$

Konseling yang dilakukan pada responden penelitian harus dilakukan dengan dasar kerjasama dan komunikasi yang baik antara konselor (peneliti/asisten peneliti) dan ibu. Pada saat konseling, konselor harus mampu menunjukkan sikap terbuka dan bersedia menjadi pendengar yang baik agar dapat menggali sejauh mana pengetahuan Ibu mengenai menyusui dan mengembangkan pengetahuan tersebut menjadi lebih baik. Keberhasilan konseling juga akan bergantung pada kemampuan konselor untuk menumbuhkan kepercayaan dan motivasi ibu sehingga secara tidak langsung ibu memiliki keberanian untuk mengungkapkan ketidaktahuan yang dihadapi

sebelumnya. Penyampaian permasalahan menyusui yang disampaikan berdasarkan pengalaman ibu pada anak sebelumnya saat konseling juga perlu diimbangi dengan penyampaian informasi yang benar sesuai

dengan perkembangan ilmu laktasi. Penyampaian penyelesaian permasalahan menyusui seyogyanya disampaikan dalam bahasa yang mudah dipahami di tengah situasi yang nyaman dan terbuka. Hal ini pada akhirnya akan mampu mengarahkan ibu untuk lebih mudah memahami dan mengingat apa yang disampaikan oleh konselor menyusui. ${ }^{26}$ Pembentukan perilaku kesehatan yang didasari atas pembentukan motivasi ternyata tidak hanya dipengaruhi oleh faktor-faktor yang berasal dari diri manusia itu sendiri (faktor internal) namun dipengaruhi pula oleh faktorfaktor yang berasal dari luar (faktor eksternal). Green dan Kreuter (1991) mengajukan suatu kerangka teori komprehensif yang menjelaskan keterkaitan antara berbagai faktor dengan perilaku kesehatan tertentu. Perilaku kesehatan dipengaruhi oleh faktor predisposisi, faktor pemungkin, faktor penguat dan lingkungan. Faktor predisposisi adalah faktor dari diri seseorang untuk melakukan perilaku kesehatan yang meliputi pengetahuan dan motivasi, sedangkan faktor pemungkin berupa fasilitas yang tersedia untuk mendukung pelaksanaan perilaku kesehatan dan faktor penguat adalah faktor yang ikut mendorong terlaksananya perilaku kesehatan. ${ }^{16}$

Studi determinan perilaku kesehatan yang dilakukan oleh Abdullah (2012) membagi faktor-faktor yang berhubungan dengan pemberian ASI eksklusif menjadi faktor predisposisi, faktor pemungkin, dan faktor penguat. Faktor predisposisi diantaranya usia ibu, tingkat pendidikan, keterpaparan informasi, sikap dan penerimaan terhadap kelahiran, pekerjaan ibu, pengalaman menyusui, dan kebiasaan ibu beserta keluarga. Faktor pemungkin yaitu ketersediaan fasilitas menyusui dan pandangan budaya terhadap menyusui. Sedangkan faktor penguat terdiri dari dukungan 
keluarga, dukungan suami, dukungan pengasuh, dukungan tenaga kesehatan dan dukungan dari instansi/perusahaan. ${ }^{28}$

Faktor ekstrinsik motivasi dapat berasal dari dukungan keluarga, dukungan suami, dukungan dari tenaga kesehatan dan sosial budaya masyarakat sekitar. ${ }^{15}$ Faktor ekstrinsik lain yang dapat mempengaruhi motivasi ibu menyusui juga adalah perubahan yang terjadi di dalam lingkungannya, penghargaan, pujian umumnya dibutuhkan oleh ibu menyusui yang telah melakukan kegiatan menyusui yang sangat bermanfaat bagi ibu dan bayinya. ${ }^{29}$

Kurangnya kesadaran atau pengetahuan tentang pentingnya pemberian ASI eksklusif akan berdampak pada menurunnya motivasi ibu dalam pemberian ASI eksklusif. Motivasi yang dimiliki oleh ibu merupakan faktor penentu peningkatan angka keberhasilan pemberian ASI. $^{30}$ Namun, motivasi yang diperoleh ibu seharusnyatidakhanyaterbataspada

peningkatan motivasi internal akan tetapi juga mencakup faktor-faktor yang mampu menguatkan motivasi eksternal yang diterima oleh Ibu.
Faktor-faktor eksternal yang telah disebutkansebelumnyasangat mungkin mempengaruhi responden di dalam penelitian ini sehingga hasil analisis perbedaan pengaruh perlakuan (konseling dan penyuluhan) terhadap nilai motivasi menyusui pada kedua kelompok perlakuan ditemukan tidak adanya perbedaan yang signifikan. Perlakuan atau intervensi yang diberikan hanya mampu meningkatkan motivasi internal responden penelitian namun tidak dapat melakukan kontrol atau modifikasi pada sumber motivasi eksternal yang sangat dipengaruhi sekali oleh faktor pemungkin dan faktor penguat di dalam determinan terbentuknya perilaku kesehatan.

\section{Praktik Pemberian ASI}

Analisis uji beda dilakukan pada variabel praktik pemberian ASI untuk membandingkan nilai skor observasi praktik pemberian ASI pada kedua kelompok yang berbeda yaitu kelompok konseling dan kelompok perlakuan. Uji beda yang digunakan adalah uji Mann-Whitney.

Tabel 5 Perbedaan Nilai Skor Observasi Menyusui Pada Dua Kelompok Perlakuan

\begin{tabular}{lccccc}
\hline \multicolumn{1}{c}{ Variabel } & $\mathrm{n}$ & Mean & SD & $95 \%$ CI & P value \\
\hline Skor Observasi & & & & $0,292-0,310$ & 0,298 \\
Kelompok Konseling & 23 & 10,13 & 4,434 & & \\
Kelompok Penyuluhan & 23 & 8,96 & 4,436 & & \\
\hline
\end{tabular}

Dari tabel 5, didapatkan nilai p 0,298 (> 0,05), sehingga dapat disimpulkan bahwa hasil nilai skor observasi menyusui diantara kedua kelompok perlakuan tidak ditemukan adanya perbedaan yang signifikan.

Pada penelitian ini, hasil analisis skor observasi praktik pemberian ASI ternyata tidak dipengaruhi oleh kedua perlakuan, baik itu 
setelah dilakukannya konseling maupun penyuluhan. Walaupun jika dilihat dari nilai rata-rata skor observasi akan dapat dilihat ratarata observasi praktik pemberian ASI pada kelompok konseling jauh lebih baik jika dibandingkan dengan kelompok penyluhan. Hal ini sesuai dengan penelitian yang dilakukan oleh Aidan, et al. (2005) di Ghana yang menyatakan bahwa ibu yang memperoleh konseling laktasi melakukan praktik pemberian ASI eksklusif yang lebih tinggi dibandingkan dengan ibu yang tidak memperoleh konseling laktasi. ${ }^{31}$

Terkait praktik pemberian ASI yang dipengaruhi oleh pendidikan kesehatan, studi yang dilakukan oleh Suryaningsih (2012)

menyatakan bahwa didapatkan adanya peningkatan yang signifikan antara skor kemampuan ibu dalam pemberian ASI sebelum dan sesudah dilakukannya demonstrasi dan pendampingan menyusui. Studi tersebut menggunakan alat observasi kemampuan ibu dalam pemberian ASI yang sama dengan yang digunakan pada penelitian ini, yaitu lembar bantuan pengamatan menyusui WHO. ${ }^{27}$

Berbeda dengan studi yang dilakukan oleh Yanthi (2011) yang melakukan metode edukasi pada dua kelompok yang berbeda yaitu dengan cara konseling dan penyuluhan dimana hasil yang didapatkan ternyata metode edukasi penyuluhan pada ibu hamil lebih baik daripada metode konseling terhadap keberhasilan menyusui. $^{32}$

\section{Pengaruh Konseling dan Penyuluhan}

\section{terhadap Pengetahuan, Motivasi, dan Praktik} Pemberian ASI

Berdasarkan hasil penelitian yang telah diuraikan sebelumnya, dapat disimpulkan bahwa konseling dan penyuluhan mengenai permasalahan menyusui yang diberikan pada trimester akhir kehamilan memiliki perbedaan pengaruh yang berbeda-beda terhadap pengetahuan, motivasi, dan kemampuan menyusui selama satu bulan pertama pasca persalinan. Terhadap pengetahuan menyusui dapat disimpulkan bahwa baik dilakukan konseling maupun penyuluhan diketahui mampu meningkatkan pengetahuan menyusui selama satu bulan pertama pasca persalinan dimana dari hasil analisa statistik ditemukan adanya perbedaan yang bermakna antara rata-rata nilai pengetahuan sebelum dengan sesudah dilakukan intervensi.

Hal ini berbeda dengan pengaruh konseling dan penyuluhan terhadap motivasi menyusui selama satu bulan pertama pasca persalinan. Penelitian ini menyimpulkan bahwa ternyata hanya konseling yang mampu memberikan perbedaan yang signifikan antara rata-rata nilai motivasi sebelum dengan sesudah dilakukannya intervensi. Walaupun dari hasil rerata nilai skor motivasi menyusui tampak adanya penurunan motivasi sesudah perlakuan (posttest) baik pada kelompok konseling maupun penyuluhan. Dari penelitian ini juga ditemukan bahwa tidak adanya perbedaan pengaruh antara konseling dan penyuluhan terhadap kemampuan praktik menyusui 
responden penelitian selama satu bulan pertama pasca persalinan yang cukup signifikan.

Hasil yang diperoleh pada penelitian ini menunjukkan bahwa tidak adanya perbedaan pengaruh antara perlakuan konseling dan penyuluhan yang diberikan pada kelompok yang berbeda secara signifikan. Hal ini kemungkinan disebabkan pada penelitian ini observasi kemampuan menyusui hanya dilakukan satu kali di akhir penelitian saat bayi berusia satu bulan pertama dan tidak dilakukan observasi yang sama sebagai pengulangan di waktu yang berbeda. Selain itu tidak tertutup kemungkinan terjadi bias pada saat pengukuran karena penilaian observasi ini dilakukan tidak hanya oleh peneliti saja namun juga oleh konselor laktasi (asisten peneliti) yang sudah memiliki sertifikat untuk bekerja sebagai konselor laktasi.

Faktor lain yang mungkin berpengaruh adalah faktor-faktor eksternal yang mempengaruhi praktik pemberian ASI yang tidak dapat dikontrol pada penelitian ini. Berdasarkan studi kualitatif yang dilakukan oleh Street \& Lewallen (2013) terhadap 186 responden wanita ras afro-amerika dan ras kulit putih untuk melihat pengaruh budaya terhadap praktik pemberian ASI didapatkan hasil bahwa praktik pemberian ASI selain dipengaruhi oleh pengetahuan ibu terhadap manfaat ASI juga sangat dipengaruhi oleh keluarga, teman atau komunitas, dan kepercayaan diri ibu. ${ }^{33}$

Penelitian ini juga melihat frekuensi dan persentase dari praktik pemberian ASI yaitu bagaimana bayi mendapatkan makanannya sehari-hari. Dari kedua kelompok tersebut kemudian didata apakah bayi dari responden penelitian mendapatkan ASI secara eksklusif, ASI parsial ataukah menghentikan kegiatan menyusui. Dikatakan seorang bayi mendapatkan ASI eksklusif jika bayi hanya menerima ASI saja termasuk ASI perah atau bayi menyusui dari orang lain tanpa asupan cairan tambahan seperti susu formula ataupun susu non ASI. ${ }^{4,34}$ ASI parsial (ASI komplementer) jika bayi mendapat tambahan selain ASI berupa makanan padat atau setengah padat lainnya termasuk susu formula dan susu non ASI. ${ }^{4,34}$ Lawrence (2013) membagi ASI parsial ini menjadi 3 kategori yaitu tinggi (asupan ASI > 80\% dari total kebutuhan nutrisi), sedang (asupan ASI $20-79 \%$ dari total kebutuhan nutrisi), dan rendah (asupan ASI $<20 \%$ dari total kebutuhan nutrisi). ${ }^{35}$

Dari penelitian ini didapatkan data bahwa jika dibandingkan antara kedua kelompok maka bayi yang mendapatkan ASI eksklusif jauh lebih banyak jumlahnya pada kelompok penyuluhan $(\mathrm{n}=16)$ dibandingkan kelompok konseling $(\mathrm{n}=$ 14). Sedangkan yang mendapatkan ASI parsial jumlahnya lebih banyak pada kelompok konseling $(\mathrm{n}=7)$ dibandingkan kelompok penyuluhan $(\mathrm{n}=5)$. Jumlah bayi yang berhenti menyusui antara kedua kelompok tidak ada perbedaan, baik pada kelompok konseling maupun penyuluhan $\mathrm{n}=2$.

Studi deskriptif dilakukan oleh Racine, et al. (2002) pada 41 wanita yang menjalani persalinan dengan bayi tunggal dibagi menjadi dua kelompok perlakuan yaitu kelompok kontrol 
mendapatkan perawatan nifas dan kelompok perlakuan yang mendapatkan kunjungan rumah secara intensif oleh tenaga kesehatan atau konselor laktasi selama 6 bulan pasca persalinan. Studi tersebut menunjukkan hasil bahwa pada kelompok perlakuan memiliki angka kunjungan bayi sakit yang lebih rendah daripada kelompok kontrol serta durasi menyusui yang lebih lama jika dibandingkan dengan kelompok kontrol. ${ }^{25}$ Sehingga dapat disimpulkan bahwa salah satu faktor yang mendukung keberhasilan pemberian ASI eksklusif (memperpanjang durasi menyusui) adalah dukungan dari tenaga kesehatan ataupun konselor laktasi.

Ditinjau dari karakteristik responden, baik pada kelompok konseling maupun penyuluhan tidak ada karakter yang dapat dianggap sebagai perancu atau confounding pada penelitian ini. Dari semua karakter yang didata oleh peneliti hasil analisis menunjukkan terdapat homogenitas di antara kedua kelompok tersebut. Peneliti sebisa mungkin telah melakukan kontrol terhadap faktor-faktor perancu, namun peneliti menyadari bahwa terdapat faktor-faktor lain yang dapat mempengaruhi responden terkait pemberian ASI seperti faktor pemungkin dan faktor penguat yang tidak mampu peneliti kendalikan. Sehingga, faktor-faktor tersebut dapat menjadi perancu pada penelitian ini.

Penelitian lanjutan diharapkan mampu memperbaiki kekurangan pada penelitian ini yaitu dengan metode yang lebih efektif agar faktor-faktor yang menjadi perancu pada penelitian ini juga mampu dikendalikan. Selain itu jumlah sampel penelitian yang terlalu kecil, menurut peneliti juga menjadi salah satu alasan didapatkan hasil yang tidak cukup signifikan di antara kedua kelompok perlakuan terutama pada motivasi dan kemampuan menyusui responden.

\section{KESIMPULAN DAN SARAN}

Kesimpulan yang didapat dari penelitian ini antara lain adalah:

1. Konseling dan penyuluhan mengenai permasalahan menyusui yang diberikan pada trimester akhir kehamilan efektif dalam meningkatkan pengetahuan menyusui selama satu bulan pertama pasca persalinan secara signifikan.

2. Konseling dan penyuluhan mengenai permasalahan menyusui yang diberikan pada trimester akhir kehamilan tidak efektif dalam meningkatkan motivasi menyusui selama satu bulan pertama pasca persalinan secara signifikan.

3. Konseling dan penyuluhan mengenai permasalahan menyusui yang diberikan pada trimester akhir kehamilan tidak memiliki pengaruh terhadap kemampuan menyusui selama satu bulan pertama pasca persalinan secara signifikan.

Penelitian lanjutan diharapkan mampu mengontrol faktor-faktor penentu keberhasilan pemberian ASI eksklusif lainnya yang berasal dari eksternal ibu menyusui seperti dukungan suami, dukungan keluarga dan dukungan tenaga kesehatan. Selain itu, juga diharapkan mampu 
melakukan studi mendalam mengenai peran dari faktor predisposisi, faktor pemungkin, dan faktor penguat yang dapat mempengaruhi pemberian ASI eksklusif.

$$
\text { Pengembangan media pendidikan }
$$

kesehatan terkait isu permasalahan menyusui perlu dilakukan sehingga dapat dijadikan acuan dalam kegiatan pendidikan kesehatan lanjutan untuk memberikan informasi dan arahan kepada ibu hamil dan menyusui agar mampu mengatasi permasalahan menyusuinya dan memperpanjang durasi praktik pemberian ASI.

\section{UCAPAN TERIMAKASIH}

Ucapan terimakasih disampaikan peneliti kepada Fakultas Kedokteran Universitas Islam Malang yang telah mendukung pelaksanaan penelitiaan melalui hibah dana bantuan penelitian dosen.

\section{REFERENSI}

1. WHO. 2011. Pelatihan Konseling Menyusui. Jakarta: Sentra Laktasi Indonesia.

2. WHO. 2009. The WHO Global Data Bank on Infant and Young Child Feeding. World Health Organization.

3. IBFAN. 2010. The State of Breastfeeding in 33 Countries. Delhi, India : BPNI/IBFAN Asia.

4. WHO \& UNICEF. 2010. Countdown to 2015 Decade Report (2000-2010): Taking Stock of Maternal, Newborn, and Child Survival. Geneva, Switzerland.

5. Kementerian Kesehatan RI. 2010. Riset Kesehatan Dasar (Riskesdas) 2010. Badan Penelitian dan Pengembangan Kesehatan.

6. Lamontagne, C., Hamelin, A. M., \& St-Pierre, M. 2008. The breastfeeding experience of women with major difficulties who use the services of a breastfeeding clinic: a descriptive study. International Breastfeeding Journal 3:17.

7. Februhartanty, J., Bardosono, S., \& Septiari, A. M. 2006. Problems During Lactation are Associated with Exclusive Breastfeeding in DKI Jakarta Province: Father's Potential Roles in Helping to Manage These Problems. Mal J Nutr, 12(2), $167-180$.

8. Mallikarjuna, H. B., Banapurmath, C. R., Banapurmath, S. \& Kesaree, N. 2002. Breastfeeding Problems in First Six Months of Life in Rural Karnataka. Indian Pediatrics 39: 861-864.

9. Manjilala. 2012. The Experience of Breastfeeding Problems During The First Six Months Period After Delivery Among Mothers Having Infants Aged 6-12 Months. Thesis. Jakarta: Nutrition Program, Faculty of Medicine University of Indonesia.

10. Abou-Dakn, M., Schafer-Graf, U. \& Wockel, A. 2009. Psychological stress and breast diseases during lactation. Breastfeeding Review 17: 1926.

11. Saleh, A., Nurachmah, E., As'ad, S., \& Hadju, V. 2009. Pengaruh Pendidikan Kesehatan dengan Pendekatan Modelling terhadap Pengetahuan, Kemampuan, Praktek dan Percaya Diri Ibu dalam Menstimulasi Tumbuh Kembang Bayi 0-6 bulan di Kabupaten Maros. Tesis: Pascasarjana, Universitas Hasanuddin.

12. Siregar, M. A. 2007. Pemberian ASI Eksklusif dan Faktor-faktor yang Mempengaruhinya. Artikel: Fakultas Kesehatan Masyarakat, Universitas Sumatera Utara

13. Man Ku, C. \& Chow, S. K. Y. 2010. Factors influencing the practice of exclusive breastfeeding among Hongkong Chinese women: A questionnaire survey. Journal of Clinical Nursing (19): 2434-2445.

14. UNICEF. 2011. Desk Review Studies on Factors Affecting Breastfeeding Practices in Indonesia. Jakarta: UNICEF Indonesia.

15. Stockdale,J., et al. 2008. Assessing the impact of midwives instruction: The breastfeeding motivational instructional measurement scale. Evidence Based Midwivery, 6(1), 27-34.

16. Notoatmodjo, S. 2010. Promosi Kesehatan dan Ilmu Perilaku Kesehatan. Jakarta: Rineka Cipta.

17. Departemen Kesehatan RI, Pusat Promosi Kesehatan. 2008. Pedoman Pengelolaan Promosi Kesehatan, dalam Pencapaian PHBS. Jakarta.

18. Sari, M. M. 2009. Pengaruh Penyuluhan Manajemen Laktasi terhadap Pengetahuan dan 
Sikap Bidan tentang Manajemen Laktasi di

Kecamatan PeusanganKabupaten Bireuen Tahun 2009. Skripsi: Fakultas Kesehatan Masyarakat, Universitas Sumatera Utara.

19. Muslikha, P., Purwanti, S. Peran Leaflet ASI

Eksklusif Terhadap Pengetahuan Ibu Tentang

ASI Eksklusif dan Motivasi Untuk Menyusui

Secara Eksklusif di BPS NY. Djuwedah

Kebasen Kabupaten Banyumas. Jurnal Ilmiah

Kebidanan, Vol.2 No.1 Edisi Juni 2011.

20. Aswa, R. 2010. Faktor yang berhubungan dengan Pemberian ASI Eksklusif di Wilayah Kerja Puskesmas Bonto Perak Kabupaten Pangkep Tahun 2010. Skripsi: Fakultas Kesehatan Masyarakat, Universitas Hasanuddin.

21. Van Gobel, H., Masni, dan Arsin, A. A. 2012. Determinan Pemberian ASI Eksklusif di

Wilayah Kerja Puskesmas Mongolato Kecamatan Telaga Kabupaten Gorontalo. Tesis: Fakultas Kesehatan Masyarakat, Universitas Hasanuddin.

22. Hikmawati, I. 2008. Faktor-faktor Resiko Kegagalan Pemberian ASI Selama Dua Bulan (Studi Kasus pada Bayi Umur 3 - 6 bulan di Kabupaten Banyumas). Tesis: Program Pascasarjana, Universitas Diponegoro.

23. Pechlivani, F., Vasiilakou, T., Sarafidou, J., Zachou, T., Anastasiou, C. A., \& Sidossis, L. S. 2005. Prevalence and determinants of exclusive breastfeeding during hospital stay in the area of Athens, Greece. Acta Pediatrica 94 : 928 - 934.

24. WHO. 2003. Global Strategy for Infant and Young Child Feeding. Geneva: World Health Organization.

25. Racine, E. F., Frick, K. D., Strobino, D., Laura, M., Carpenter, L. M., Milligan, R., \& Pugh, L. C. 2011. How motivation influences breastfeeding duration among low-income women. J Hum Lact, 25(2), 173-18.

26. Ambarwati, R., Muis, S. F., \& Susantini, P. 2013. Pengaruh konseling laktasi intensif terhadap pemberian air susu ibu (ASI) eksklusif sampai 3 bulan. Jurnal Gizi Indonesia 2(1): 15 23.
27. Suryaningsih, C. 2012. Pengaruh Demonstrasi dan Pendampingan Menyusui Terhadap Motivasi dan Kemampuan Ibu dalam Pemberian ASI. Tesis. Jakarta: Program Magister Ilmu Keperawatan, Fakultas Ilmu Keperawatan Universitas Indonesia.

28. Abdullah, G. I. 2012. Determinan Pemberian ASI Eksklusif pada Ibu Bekerja di Kementerian Kesehatan RI Tahun 2012. Tesis. Jakarta: Fakultas Ilmu Kesehatan Masyarakat Universitas Indonesia.

29. Hariandja, M. 2007. Manajemen Sumber Daya Manusia. Jakarta: Grasindo.

30. Roesli, U. 2008. Inisiasi Menyusui Dini dan ASI Eksklusif. Jakarta: Trubus Agriwidya.

31. Aidan, B. A., Escamilla, R. P., Lartey, A. 2005. Lactation Counseling Increase Exclusive Breast-Feeding Rates in Ghana. Journal of Nutrition 135: 1691-1695.

32. Yanthi, D. 2011. Keefektifan Metode Edukasi pada Ibu Hamil Terhadap Keberhasilan Menyusui. Tesis: Universitas Gajah Mada, Yogyakarta.

33. Street DJ, Lewallen LP. The influence of culture on breastfeeding decisions by African American women and white women. $J$ Perinat Neonat Nurs. 2013;27(1):43-51.

34. WHO. 2007. Indicators for Assessing Infant and Young Child Feeding Practices. Conclusions of a consensus meeting of WHO. Washington DC, USA.

35. Lawrence, R. A. and Lawrence, R. M. 2011. Breastfeeding: A Guide for the Medical Profession. USA: Elsevier, Inc. 